\title{
Autoradiographic determination of angiotensin II receptors in prepubertal and postpubertal pig ovarian tissue
}

\author{
G. Shuttleworth ${ }^{1 *}$, M. G. Hunter ${ }^{2}$ and F. Broughton Pipkin ${ }^{1}$ \\ ${ }^{1}$ Division of Obstetrics and Gynaecology, School of Human Development, University of \\ Nottingham, Queens Medical Centre, Nottingham NG7 2UH, UK; and ${ }^{2}$ Division of Animal \\ Physiology, School of Biosciences, University of Nottingham, Sutton Bonington, \\ Leicestershire LE12 5RD, UK
}

The aim of this study was to determine whether specific receptors for angiotensin II are present in prepubertal and postpubertal pig ovaries using an autoradiographic technique and computerized densitometry. Frozen sections were cut from prepared samples, and ${ }^{125}$ I-labelled angiotensin II and the angiotensin II receptor subtypespecific nonpeptide antagonists for receptor subtype 1, $\mathrm{AT}_{1}$ (GR117289) and subtype 2, $\mathrm{AT}_{2}$ (PD123319) were used. In both pre- and postpubertal pig ovarian tissue, specific receptors for angiotensin II were demonstrated. These receptors had a density of 2487.6 (range: 267.5-5177.6, $n=4$ ) and 3703.8 (range: 1819.9-5207.8, $n=4) \mathrm{fmol}$ per $\mathrm{mm}^{2}$, respectively, and dissociation constants of 130.0 and $26.3 \mathrm{nmol} \mathrm{I}^{-1}$, respectively (prepubertal ovarian range: $106.0-165.4 \mathrm{nmol}^{-1}$; postpubertal ovarian range: $26.1-100.3 \mathrm{nmol} \mathrm{I}^{-1} ; P<0.05$, Mann-Whitney $U$ test). $\mathrm{AT}_{1}$ receptors with a $K_{\mathrm{i}}$ for ${ }^{125}$ I-labelled angiotensin II of $346.9 \mathrm{nmol} \mathrm{I}^{-1}$ in the prepubertal and $268.1 \mathrm{nmol} \mathrm{I}^{-1}$ in the postpubertal ovary were located predominantly in follicle wall tissue. Competitive inhibition studies using both angiotensin II antagonists resulted in a decrease in $K_{\mathrm{i}}$ with prepubertal tissue $\left(283.7 \mathrm{nmol} \mathrm{I}^{-1}\right)$ and an increase in postpubertal tissue $\left(293.9 \mathrm{nmol} \mathrm{I}^{-1}\right)$. Immunocytochemistry using sections from paraffin wax-embedded prepubertal $(n=4)$ and postpubertal $(n=4)$ pig ovaries confirmed the presence of $\mathrm{AT}_{1}$ receptors on the granulosa cell layer, but not the thecal cell layer, of antral follicles in both pre- and postpubertal pig ovarian tissue, and $\mathrm{AT}_{2}$ receptors within the granulosa cell layer of prepubertal pig ovarian antral follicles. In summary, these results indicate that angiotensin II receptors are of higher affinity in postpubertal tissue than they are in prepubertal tissue, and indicate an active renin-angiotensin system within the pig ovary.

\section{Introduction}

There is considerable evidence for a local reninangiotensin system in the mammalian ovary (Bumpus et al., 1988; Lightman et al., 1989; August and Sealey, 1990). The principal biologically active product of this cascade reaction is the octapeptide, angiotensin II (AngII), which acts through specific receptors, potentially to influence ovulation and steroidogenesis (Pellicer et al., 1988; Yoshimura et al., 1992; Peterson et al., 1993). The two main types of Angll receptor, type $1\left(\mathrm{AT}_{1}\right)$ and type $2\left(\mathrm{AT}_{2}\right)$, have been classified using antagonists (Chiu et al., 1989; Whitebread et al., 1989; Timmermans et al., 1993), primarily Losartan (a well characterized $\mathrm{AT}_{1}$ antagonist) and PD 123319 (an $\mathrm{AT}_{2}$ receptor antagonist). Glaxo compound GR117289 can also be used as an $\mathrm{AT}_{1}$ antagonist (Robertson et al., 1992). $\mathrm{AT}_{1}$ receptors are involved in the regulation of vasoconstriction and salt and fluid balance

*Present address and correspondence: Reproductive Technologies, Agresearch, Ward Street, PO Box 40063, Upper Hutt, Wellington, New Zealand

Email: gail.shuttleworth@agresearch.co.nz
(Chiu et al., 1989; Whitebread et al., 1989), whereas $\mathrm{AT}_{2}$ receptors are thought to play a role in growth regulation and apoptosis (Timmermans et al., 1993). However, there is a general paucity of information regarding the presence or absence of $\mathrm{AT}_{1}$ and $\mathrm{AT}_{2}$ receptors within the mammalian ovary.

$A T_{2}$ receptors have been identified in cultured bovine thecal cells by preparing a cell membrane fraction and conducting an ${ }^{125} \mathrm{I}$-binding study (Brunswig-Spickenheier and Mukhopadhyay, 1992a,b). Receptor autoradiography may be used to determine the presence of the receptor for a particular ligand within a type of tissue. Autoradiographic studies have demonstrated Angll receptor binding sites on rat granulosa cells (Daud et al., 1989; Naftolin et al., 1989), and on rat granulosa and theca interna cells (Husain et al., 1987). Another autoradiographic study localized Angll receptors to granulosa cells within atretic follicles of the rat ovary (Daud et al., 1988). However, these studies did not differentiate between the two characterized Angll receptor subtypes.

The present study used radiolabelled Angll to identify and locate receptors. This method has been used widely to process large numbers of ovarian samples, for example in 
localizing the type 1 IGF (insulin-like growth factor) receptor in the ovine ovary (Perks et al., 1995), and ovarian gonadotrophin receptors in the rhesus monkey (Hutz et al., 1993), human (Yamoto et al., 1992) and rat ovary (Otani et al., 1996). Quantitative receptor autoradiography in vitro is well established as a method to measure receptor binding to different regions of tissue (Palacios et al., 1981; Som et al., 1983; Yonekura et al., 1983; Israel et al., 1985; Zilles et al., 1988, 1990).

There is some evidence of components of the reninangiotensin system within the pig ovary. Prorenin and renin are present in pig follicular fluid (Hagemann et al., 1992; Nielsen et al., 1995). Previous studies in our laboratory have demonstrated renin activity in follicular fluid collected from small (1-3 $\mathrm{mm}$ in diameter) prepubertal follicles and at a lower level in larger (>6 mm in diameter) postpubertal follicles (Shuttleworth, 2000). Angll inhibits the transcription of steroidogenic enzymes in pig granulosa cells, indicating an active role for this peptide in pig ovarian function ( $\mathrm{Li}$ et al., 1995). Nielsen et al. (1995) used a membrane fraction Angll receptor assay to indicate that there are receptors present in postpubertal pig follicle wall tissue, but did not characterize them.

Therefore, the aim of the present study was to use autoradiography to determine whether there are receptors for Angll within the prepubertal and postpubertal pig ovary, and if so, to identify whether they are $\mathrm{AT}_{1}$ or $\mathrm{AT}_{2}$ subtypes. Such findings would give an indication of the role of Angll in the pig ovary. Computerized densitometry was applied to analyse ligand binding and hence determine the binding affinity $\left(K_{\mathrm{d}}\right.$ or $\left.K_{\mathrm{i}}\right)$ and binding capacity $\left(B_{\max }\right)$ of the receptor. Immunocytochemistry was used to localize the receptor subtypes to types of follicular cell within the preand postpubertal pig ovary.

\section{Materials and Methods}

\section{Tissue and slide preparation}

Prepubertal (12-15 weeks of age) and postpubertal ovarian tissue from Large White hybrid pigs was obtained from a local abattoir and transported to the laboratory on ice. Follicles within prepubertal ovaries were $<5 \mathrm{~mm}$ in diameter and there was no evidence of previous ovulation. Postpubertal ovarian samples were selected as being those in the follicular phase with several large follicles $>6 \mathrm{~mm}$ in diameter (Grant et al., 1989), and therefore presenting no active corpora lutea, although corpora albicantia from previous cycles were present. These selection criteria ensured that similar structures (that is, follicles) in pre- and postpubertal ovaries were being compared. Both ovaries from five prepubertal and eight postpubertal animals were selected, dissected free of surrounding tissue and frozen in liquid nitrogen within $1 \mathrm{~h}$ of slaughter. Serial frozen sections $(20 \mu \mathrm{m})$ were cut on a cryostat at $-30^{\circ} \mathrm{C}$, and duplicate consecutive sections were thaw-mounted on gelatin-coated slides. Slides were stored with desiccant at $-80^{\circ} \mathrm{C}$ and brought to room temperature immediately before use. Ovaries from a further four prepubertal and four postpubertal animals at a similar age or stage of the oestrous cycle as those used in the autoradiographic study were prepared and processed for embedding in paraffin wax. Four postpubertal adrenal glands were also prepared as per the ovarian samples and embedded in paraffin wax as positive controls. Serial sections $(4 \mu \mathrm{m})$ were cut and mounted on glass slides pre-coated with 2.5\% (v/v) 3aminopropyltriethoxysilane (APES; Sigma Chemical Co., Poole) in acetone. Slides were stored at room temperature before immunocytochemical staining.

\section{In vitro autoradiography}

Prepared slides of frozen sections were preincubated at room temperature for at least $30 \mathrm{~min}$ in $50 \mathrm{mmol}$ sodium phosphate buffer $\mathrm{I}^{-1}\left(\mathrm{pH}\right.$ 7.2) containing $150 \mathrm{mmol} \mathrm{NaCl} \mathrm{I}^{-1}$, $10 \mathrm{mmol} \mathrm{MgCl}_{2} \mathrm{I}^{-1}, 5 \mathrm{mmol}$ EDTA $\mathrm{I}^{-1}$ (disodium salt), $0.4 \%$ $(\mathrm{w} / \mathrm{v}) \mathrm{BSA}$ and $0.005 \%(\mathrm{w} / \mathrm{v})$ bacitracin (all Sigma Chemical Co.). The slides were incubated for $3 \mathrm{~h}$ at room temperature in a humidified chamber in fresh buffer containing increasing concentrations $\left(10^{-12}-10^{-4} \mathrm{~mol} \mathrm{I}^{-1}\right)$ of the appropriate unlabelled ligand and $0.3 \mathrm{nmol}{ }^{125} \mathrm{I}$-labelled AngIl ${ }^{-1}$ (Amersham Pharmacia Biotech UK Ltd, Little Chalfont). Serial consecutive sections were incubated with increasing concentrations of unlabelled Angll to determine the specificity of Angll binding ( $n=4$ prepubertal ovaries, $n=4$ postpubertal ovaries). Serial sections were incubated with increasing concentrations $\left(10^{-12}-10^{-4} \mathrm{~mol} \mathrm{I} \mathrm{I}^{-1}\right)$ of the $\mathrm{AT}_{1}$ receptor antagonist GR117289 (GlaxoSmithKline plc, Uxbridge), the $\mathrm{AT}_{2}$ receptor antagonist PD123319 (ParkeDavies and Co. Ltd, Eastleigh) or a combination of GR117289 and PD123319 to characterize Angll receptor subtypes. After incubation, slides were washed twice for 5 min in sodium phosphate buffer at $4^{\circ} \mathrm{C}$, and rinsed briefly in distilled water. The sections were dried in a stream of cool air. Slides were placed in a light tight X-ray cassette (Genetic Research Instruments Ltd, Braintree) with one set of 125 | microscale standards (mean values from 3552 to 1360860 d.p.m. mg $^{-1}$; Amersham Pharmacia Biotech UK Ltd) and apposed to Hyperfilm ${ }^{3} \mathrm{H}$ X-ray film (Amersham Pharmacia Biotech UK Ltd). The cassette was stored at room temperature for 5 days. The film was developed for 2.5 min in Kodak D19 developer (Sigma Chemical Co.) and rinsed briefly in tap water containing 1\% (v/v) acetic acid and fixed for $5 \mathrm{~min}$ in Ilford Hypam Fixer (Ilford Ltd, Knutsford). The film was washed in running tap water for $20 \mathrm{~min}$ and air-dried. Slides were fixed in $10 \%(\mathrm{v} / \mathrm{v})$ formol saline, and stained with haematoxylin and eosin to aid in identifying structures and type of cell to which ${ }^{125}$ I-labelled Angll had bound.

\section{Image analysis and computerized densitometry}

Areas of the ovarian section that bound ${ }^{125}$ I-labelled Angll produced a dark image when apposed to X-ray film. The film was analysed by computer densitometry to assess the binding of ${ }^{125} \mathrm{I}$-labelled Angll to ovarian sections and to 
determine the binding kinetics (Yonekura et al., 1983; Israel et al., 1984, 1985; Saavedra et al., 1986). The developed autoradiograph was placed on a lightbox (DW Viewboxes Ltd, Milton Keynes) and viewed through a solid state video camera (COHU, San Diego, CA) linked to a computer running the Image Manager Package (Rev 5.21, Sight Systems, Foster Findlay Assoc. Ltd., Newcastle-UponTyne), which gave a reading on a greyscale from 0 to 255 corresponding to the intensity of the developed image (background automatically subtracted). Each sample was analysed to give a greyscale value from 0 to 255 , where 0 corresponds to 'black' and 255 corresponds to 'white'. Two areas were measured per ovarian section using computerized image analysis; the total area of the section including follicular antra, and the area corresponding to tissue only (not including the area occupied by follicular antra, deducted by altering the threshold setting to exclude these areas). Each standard was measured in triplicate, and a mean value determined. Grey scale values were converted to relative optical density (ROD) values.

Standards were corrected for radioactive decay and a standard curve was plotted (linear regression) of ROD versus the logarithm of this value; a good fit was considered to give an $r$ value approaching 1 (range 0.9613-0.9857, to four decimal places) and $P<0.05$. All standard curves in this study fitted this criterion. The logarithm of sample d.p.m. per $\mathrm{mm}^{2}$ was determined from the calculated ROD using the standard curve. This value was raised to the power 10, corrected for radioactive decay, and the logarithm of this corrected value was obtained. The equation generated for the standard curve was used to determine the corrected ROD. A displacement curve was plotted of the corrected ROD versus the logarithm of the concentration of the unlabelled compound studied to give a sigmoidal curve symmetrical about the dissociation constant $K_{\mathrm{d}}$ (when the displacing ligand is other than Angll, for example the receptor antagonists, this value is termed $K_{\mathrm{i}}$ ). A Scatchard plot was constructed using GraphPad Prizm v1.03 (Graphpad, San Diego, CA) and a line generated (for example, see Fig. 1). The mean area of the tissue (less antral spaces) was calculated for each series of displacement and was used in the calculation of $B_{\max }\left(\mathrm{fmol}\right.$ per $\mathrm{mm}^{2}$ ) to allow comparison between tissues. The calculated $K_{d}$ values for pre- and postpubertal ovarian tissue were analysed statistically using the Mann-Whitney $U$ test.

\section{Immunocytochemistry}

Immunocytochemistry was completed on the paraffin waxembedded sections using the Dako EnVision $+{ }^{\circledR}$ System (Dako, Ely). The protocol was as per the manufacturer's instructions except that blocking for endogenous peroxidase was undertaken using a standard methanol-hydrogen peroxide step for 15 min (Jackson and Blythe, 1993). The monoclonal antibody to the $\mathrm{AT}_{1}$ receptor (6313/G2, a kind gift from G. P. Vinson (Barker et al., 1993)) was used at a 1 in 10 dilution in Tris buffer containing $0.25 \%(\mathrm{w} / \mathrm{v}) \mathrm{BSA}$. A polyclonal anti-AT 2

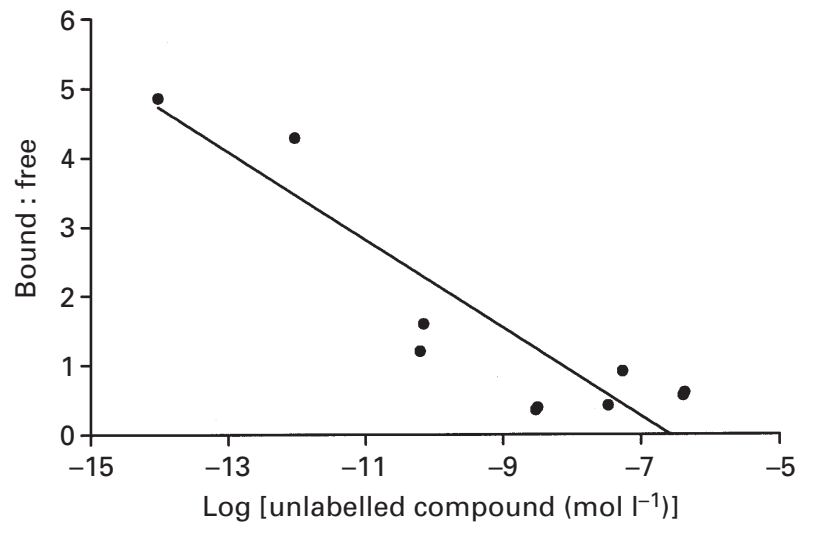

Fig. 1. Scatchard analysis of representative data obtained by the displacement of ${ }^{125}$ I-labelled angiotensin II from pig postpubertal ovarian tissue and various concentrations of unlabelled angiotensin II. $K_{\mathrm{d}}=26.6 \mathrm{nmol} \mathrm{I}^{-1}$ and $B_{\max }=5207.8 \mathrm{fmol}$ per $\mathrm{mm}^{2}$ in this experiment.

receptor antibody (a kind gift from W. T. Cheung (Yiu et al., 1997)) was used at a dilution of 1 in 4000 in Tris buffer containing $0.25 \%(w / v)$ BSA. Sections were counterstained with Harris' haematoxylin. Positive controls for both receptor subtypes comprised paraffin wax-embedded postpubertal pig adrenal gland. Negative controls initially comprised sections of all types of tissue (including adrenal gland) processed as above, with mouse non-immune serum (anti-AT ${ }_{1}$ negative control) and rabbit non-immune serum (anti- $\mathrm{AT}_{2}$ negative control). As neither control produced false positive immunoreactivity, all subsequent negative controls comprised Tris buffer containing $0.25 \%(\mathrm{w} / \mathrm{v})$ BSA replacing receptor subtype antibody in the protocol.

\section{Results}

\section{Specificity of Angll binding}

An example displacement of $0.3 \mathrm{nmol}{ }^{125}$-labelled Angll $\mathrm{I}^{-1}$ using increasing concentrations of unlabelled Angll is shown (Fig. 2). With an increasing amount of unlabelled ligand, there was an increase in displacement first observed visually between $10^{-10}$ and $10^{-8} \mathrm{~mol} \mathrm{I}^{-1}$, indicating the specific binding of Angll to receptors in both types of tissue. Some sites were identified histologically by comparison with haematoxylin and eosin stained slides as being blood vessels in which ${ }^{125}$ I-labelled Angll was not displaced with high concentrations of unlabelled ligand. Resolution of autoradiographs was not sufficient to identify conclusively other sites within ovarian stroma to which ${ }^{125}$ I-labelled Angll was bound even at $\times 200$ magnification. $K_{\mathrm{d}}$ and $B_{\max }$ values were calculated for four ovarian samples studied autoradiographically. As the postpubertal tissue data were skewed (Fig. 3), median values are given. The median $K_{\mathrm{d}}$ values for pre- and postpubertal ovarian tissue were 130.0 and $26.3 \mathrm{nmol} \mathrm{I}^{-1}$, respectively (prepubertal ovarian range: $106.0-165.4 \mathrm{nmol} \mathrm{I}^{-1}$; postpubertal ovarian range: 
(a)

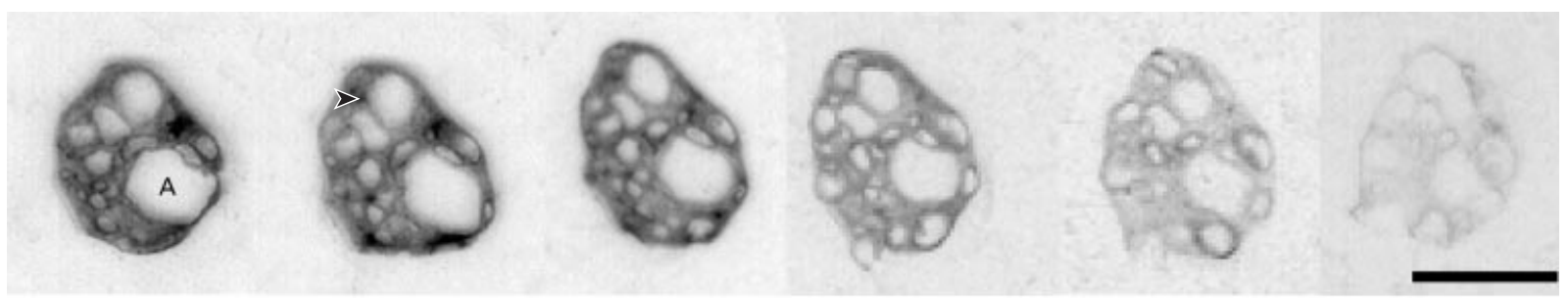

(b)

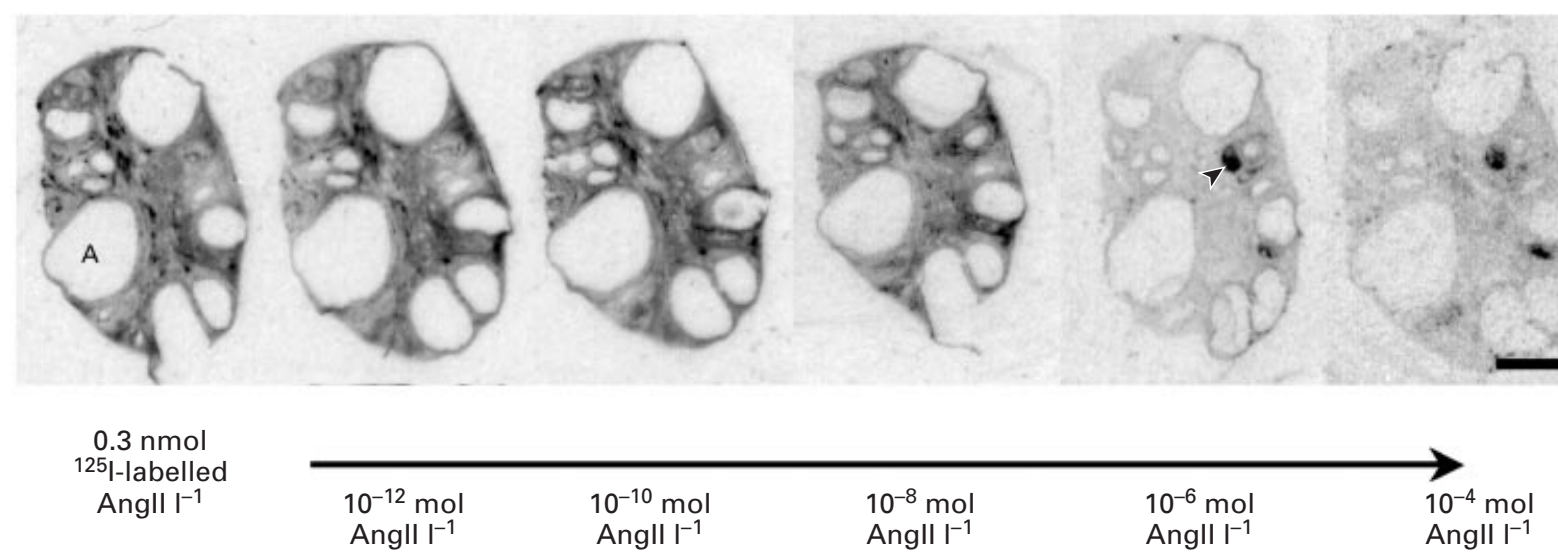

Fig. 2. Displacement of $0.3 \mathrm{nmol}{ }^{125}$ I-labelled angiotensin II (AnglI) $\mathrm{I}^{-1}$ from pig (a) prepubertal and (b) postpubertal ovarian tissue, with increasing concentrations of unlabelled Angll. Examples of blood vessels are indicated by arrowheads; examples of the antral space of an antral follicle are denoted by ' $A$ '. Scale bar for each series represents $5 \mathrm{~mm}$ (note different magnifications).

26.1-100.3 nmol I-1; $P<0.05$, Mann-Whitney $U$ test). The median $B_{\max }$ was $2487.6 \mathrm{fmol}$ per $\mathrm{mm}^{2}$ (range: 267.5-5177.6 fmol per $\mathrm{mm}^{2}$ ) for prepubertal tissue, and $3703.8 \mathrm{fmol}$ per $\mathrm{mm}^{2}$ (range: $1819.9-5207.8 \mathrm{fmol}$ per $\mathrm{mm}^{2}$ ) for postpubertal tissue. There was no significant difference between these $B_{\max }$ values.

\section{Characterization and localization of receptors}

Displacement of ${ }^{125}$ I-labelled Angll by the $\mathrm{AT}_{1}$ antagonist (GR117289) and the $\mathrm{AT}_{2}$ antagonist (PD123319) is presented (Figs 4 and 5). Displacement was seen with lower concentrations of the $\mathrm{AT}_{1}$ antagonist than the $\mathrm{AT}_{2}$ antagonist, and quantified data are presented (Table 1). It was not possible to calculate $K_{\mathrm{i}}$ for PD123319 owing to the minimal displacement observed. The $K_{\mathrm{i}}$ and $B_{\max }$ values for the $\mathrm{AT}_{1}$ antagonist calculated for prepubertal ovarian tissue were $346.9 \mathrm{nmol} \mathrm{I}^{-1}$ and $241.8 \mathrm{fmol}$ per $\mathrm{mm}^{2}$, respectively, and for postpubertal ovarian tissue were $268.1 \mathrm{nmol} \mathrm{I}^{-1}$ and $6868.8 \mathrm{fmol}$ per $\mathrm{mm}^{2}$, respectively. The use of both antagonists gave greater displacement than use of GR117289 alone (in prepubertal tissue, ROD using GR117289 alone was 0.047, and with both antagonists it was 0.042; in postpubertal tissue, ROD using GR117289 alone was 0.045 and with both antagonists it was 0.039) (Fig. 5), indicating some additional displacement due to
PD123319. Sites of binding corresponding to the theca interna-granulosa cell layers within the follicle were identified (Fig. 5). Immunocytochemical staining for the two receptor subtypes demonstrated that there were $\mathrm{AT}_{1}$ receptors clearly localized to the adrenal positive control and also to the granulosa cell layer in both pre- and postpubertal ovaries (see Fig. 6) despite predominant edgeeffect staining observed at the edge of antral follicles. There was faint immunostaining for $\mathrm{AT}_{2}$ receptors in the granulosa cell layer of prepubertal but not postpubertal antral follicles. There did not appear to be $\mathrm{AT}_{1}$ or $\mathrm{AT}_{2}$ receptors localized to the theca cell layer.

\section{Discussion}

This study shows that Angll binds specifically to receptors in the pre- and postpubertal pig ovary, and that the receptors were of higher affinity in postpubertal than in prepubertal tissue. Furthermore, most of these receptors were of the $\mathrm{AT}_{1}$ receptor subtype and were localized using immunocytochemistry to the granulosa cell layers of antral follicles. The calculated $K_{\mathrm{i}}$ values were high, indicating a low affinity receptor (high affinity receptors will have low $K_{\mathrm{d}}$ and $K_{\mathrm{i}}$ values, typically in the $<10 \mathrm{nmol} \mathrm{I}^{-1}$ range: Bumpus et al., 1988; Daud et al., 1988; Aguilera et al., 1989; Nielsen et al., 1994a, 1995). However, studies in pregnant rat uteri 
Table 1. Binding kinetics of ${ }^{125}$ I-labelled angiotensin II displacement with angiotensin II (AngII), GR117289 or PD123319 in pre- and postpubertal pig ovarian tissue

\begin{tabular}{llcc}
\hline Pig ovarian tissue & \multicolumn{1}{c}{ Antagonist } & $\begin{array}{c}\text { Binding affinity } \\
(\mathrm{nmol} \mathrm{I-1})^{+}\end{array}$ & $\begin{array}{c}B_{\max } \\
\left(\mathrm{fmol} \mathrm{per} \mathrm{mm}^{2}\right)\end{array}$ \\
\hline Prepubertal & Angll & 165.4 & 267.5 \\
Prepubertal & GR117289 & 346.9 & 241.8 \\
Prepubertal & PD123319 & $*$ & $*$ \\
Prepubertal & GR117289/PD123319 & 283.7 & 955.5 \\
Postpubertal & Angll & 26.6 & 5207.8 \\
Postpubertal & GR117289 & 268.1 & 6868.8 \\
Postpubertal & PD123319 & $*$ & $*$ \\
Postpubertal & GR117289/PD123319 & 293.9 & 937.2 \\
\hline
\end{tabular}

Each value is based on one experiment.

${ }^{+}$Binding affinity dissociation constant is $K_{\mathrm{d}}$ when Angll is the antagonist and $K_{\mathrm{i}}$ for other antagonists.

*Values could not be calculated owing to the minimal displacement observed with PD123319.

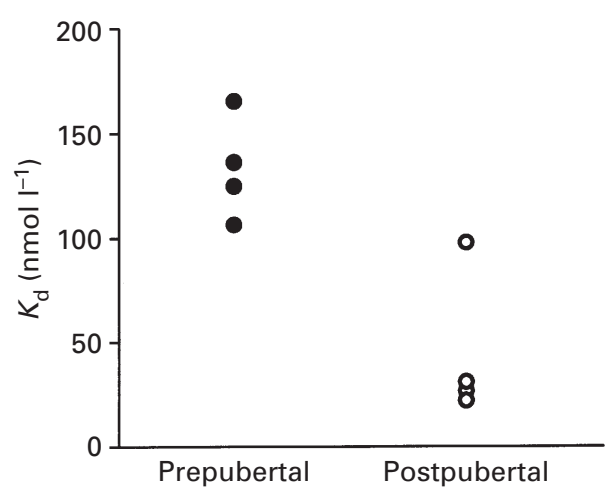

Fig. 3. Calculated $K_{d}$ values for four samples of prepubertal and postpubertal pig ovarian tissue when adding $125 \mathrm{I}$-labelled angiotensin II (AngII) with unlabelled Angll. The median $K_{\mathrm{d}}$ value is $130.0 \mathrm{nmol} \mathrm{I}^{-1}(n=4)$ for prepubertal tissue and $26.3 \mathrm{nmol} \mathrm{I}$ $(n=4)$ for postpubertal tissue. Note that there is no overlap in data from the two tissue stages.

indicate that there is a single receptor with a high $K_{d}$ value (18.3-24.2 nmol I-1: Yang et al., 1994). Thus, $K_{d}$ values differ among species and types of tissue and therefore extrapolation to pigs, for which there is a paucity of information regarding ovarian Angll receptor kinetics, is problematic.

In the present study, some sites in both tissues examined were not associated with any specific area of the ovarian stroma where the ligand bound non-specifically (that is, did not show displacement even at high concentrations of unlabelled ligand). These sites may act in a regulatory fashion to remove excess Angll from the ovary. However, the calculated median $K_{d}$ values of $26.3 \mathrm{nmol} \mathrm{I}^{-1}$ for postpubertal tissue and $130.0 \mathrm{nmol} \mathrm{I}^{-1}$ for prepubertal tissue indicate that Angll has a higher affinity for postpubertal tissue, and that there was no overlap in $K_{d}$ value between the two types of tissue. The difference in affinity between pre- and postpubertal tissue may be due to the age of the pig studied and the influence of the change in hormonal milieu between pre- and postpubertal animals. This finding is not unexpected, as a change in receptor affinity within the myometrium from the non-pregnant to pregnant state has been reported in both women (fourfold: Cox et al., 1996) and rats (9-12-fold: Yang et al., 1994). Analysis of four postpubertal ovarian samples showed one high outlier $K_{\mathrm{d}}$ value. The mean $K_{\mathrm{d}}$ and $B_{\max }$ values of the other three samples were $25.6 \mathrm{nmol} \mathrm{I}^{-1}$ and $4335.1 \mathrm{fmol}$ per $\mathrm{mm}^{2}$, respectively. The 'high' outlier gave a $K_{d}$ value of 100.3 $\mathrm{nmol} \mathrm{I}^{-1}$ and $B_{\max }$ value of $1818.9 \mathrm{fmol}$ per $\mathrm{mm}^{2}$, indicating a lower number of receptors at a lower affinity. Analysis of slides stained with haematoxylin and eosin demonstrated that this sample was at a later stage of the follicular phase of the oestrous cycle, as it contained larger antral follicles than the other three samples. Differences in Angll receptor expression during the oestrous cycle have been observed in immunocytochemical studies in rats, in which specific 125l-labelled Angll binding in stromal and thecal cells surrounding large antral follicles in normally cyclic ovaries was as follows: dioestrus > pro-oestrus > oestrus (Lightman et al., 1988). These differences indicate that as the animal proceeds through the oestrous cycle, the $K_{d}$ value increases, as supported by the present study. In contrast to the present study, there was no evidence in rats of binding in the granulosa cells of preantral or antral follicles, or immature ovaries. However, specific high affinity Angll receptors have been demonstrated predominantly on the rat granulosa cell and theca interna layers of a subpopulation of mature and immature follicles (Speth et al., 1986; Husain et al., 1987). Daud et al. (1988) reported that, of the follicles containing Angll receptor in the cyclic rat ovary, approximately 95\% showed signs of atresia and, using a membrane binding assay, showed that specific binding was lowest at oestrus and highest at dioestrus. Strong $\mathrm{AT}_{2}$ mRNA expression has been demonstrated in granulosa cells from rat follicles in tertiary stages of development exhibiting signs of atresia, and in individual collapsed atretic follicles, indicating that the $\mathrm{AT}_{2}$ receptor mediates effects leading to 




(b)

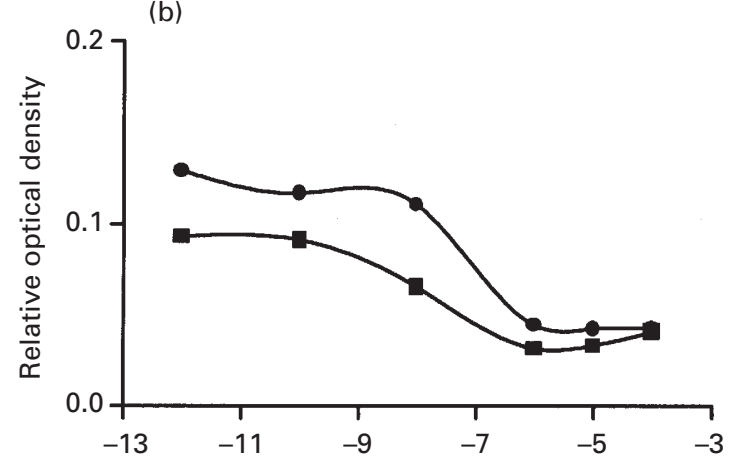

(c)

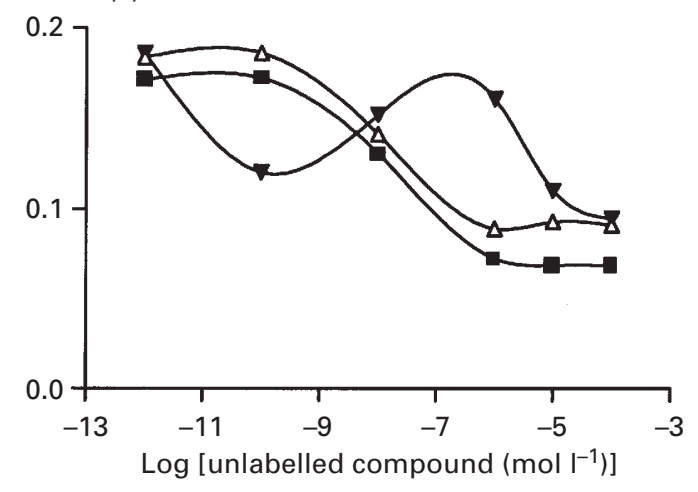

Fig. 4. ${ }^{125}$ I-Labelled angiotensin II (AngII) displacement observed

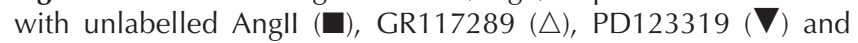
GR117289 plus PD123319 (O), using prepubertal (a) and postpubertal $(\mathrm{b}, \mathrm{c})$ pig ovarian tissue $(n=1)$.

antiproliferative actions and apoptosis (Obermuller et al., 1998). This contention was supported by a further study demonstrating that angiotensin-converting enzyme was linked to the early stages of follicular maturation and atresia (Daud et al., 1990).

The present study demonstrates for the first time that most receptors within the pig pre- and postpubertal ovary are of the $\mathrm{AT}_{1}$ subtype. The use of the pig adrenal gland as a positive control confirms that the results observed were due to the specificity of the antibodies used. This finding is in contrast to studies in other mammals (rats: Daud et al., 1988; Obermuller et al., 1998; Kotani et al., 1999; cows:
Brunswig-Spickenheier and Mukhopadhyay, 1992b; Aiyar et al., 1993; Nielsen et al., 1995) indicating the $\mathrm{AT}_{2}$ receptor subtype is associated with ovarian tissue, but is in agreement with studies on rabbit ovaries (Feral et al., 1996). In rats, workers using membrane binding assays have argued for the presence of a single receptor class, with higher concentrations found in corpora lutea and stromal tissue than in granulosa or luteal cells (Aguilera et al., 1989). However, Pucell et al. (1991) also used a membrane binding assay to demonstrate that high affinity $\mathrm{AT}_{2}$ receptors were present in rat granulosa cells and that $\mathrm{AT}_{1}$ receptors were present on other ovarian structures (that is, the thecal cell layer, interstitium, corpus luteum, blood vessels and surface epithelium). There may be confusion in the detection of the $\mathrm{AT}_{1}$ receptor in the rat, as studies have shown the presence of two forms, $\mathrm{AT}_{1 \mathrm{~A}}$ and $\mathrm{AT}_{1 \mathrm{~B}}$ (Kakar et al., 1992), and report that $\mathrm{AT}_{1 \mathrm{~A}}$ receptors have a lower affinity for Losartan (Tian et al., 1996). There are no reported differences in $\mathrm{AT}_{1}$ receptors in pigs and it appears from the results of the present study that the pig ovary possesses both characterized subtypes within its ovarian tissue.

In the bovine ovary, many studies have shown that the predominant receptor is subtype 2 (Brunswig-Spickenheier and Mukhopadhyay, 1992a,b; Aiyar et al., 1993; Nielsen et al., 1994a,b, 1995). Studies by Aiyar et al (1993) indicate that approximately $80 \%$ of Angll receptors are subtype 2 . It has been suggested that high receptor density is a feature of large bovine ovarian follicles, and reflects an increase in expression with follicular growth and that therefore, unlike in rats, Angll receptor expression is not confined to atretic follicles (Nielsen et al., 1994a,b). In the present study, it was not possible to determine the binding kinetics per follicle, and therefore the receptor density per follicle, although there did appear to be an increase in binding with increasing follicle size.

Nielsen et al. (1995) compared components of the ovarian renin-angiotensin system in bovine and pig ovaries and demonstrated that $\mathrm{AT}_{2}$ receptors in bovine corpora lutea had a $K_{\mathrm{i}}$ value of 1.01 (range $0.64-1.79$ ) $\mathrm{nmol} \mathrm{I}^{-1}$ $(n=8)$ and a $B_{\max }$ value of 22.7 (range 1.9-93) $\mathrm{fmol} \mathrm{mg}^{-1}$ membrane protein. The authors suggested that this value is ten times higher than it is in pig corpora lutea and reported that the receptor density in postpubertal pig follicular wall tissue was 35 -fold lower than it was in bovine follicles (47 (range 19-97) $\mathrm{fmol} \mathrm{mg}^{-1}$ protein; $n=13$ ). It is difficult to compare the results of Nielson et al. (1995) with the results of the present study, which are expressed in terms of the area studied in the autoradiogram. However, Nielson et al. (1995) comment that it was not possible to determine the subtype or $K_{\mathrm{i}}$ value of the receptor in the pig ovary owing to varying but low specific binding, and assume the presence of $\mathrm{AT}_{2}$ receptors, as in the bovine ovary, with binding characteristics similar to $\mathrm{AT}_{2}$ receptors in the pig placental amniochorion-endometrium, without testing the hypothesis. The present autoradiographic study demonstrates clearly the presence of $\mathrm{AT}_{1}$ receptors in the pre- and postpubertal 
(a)

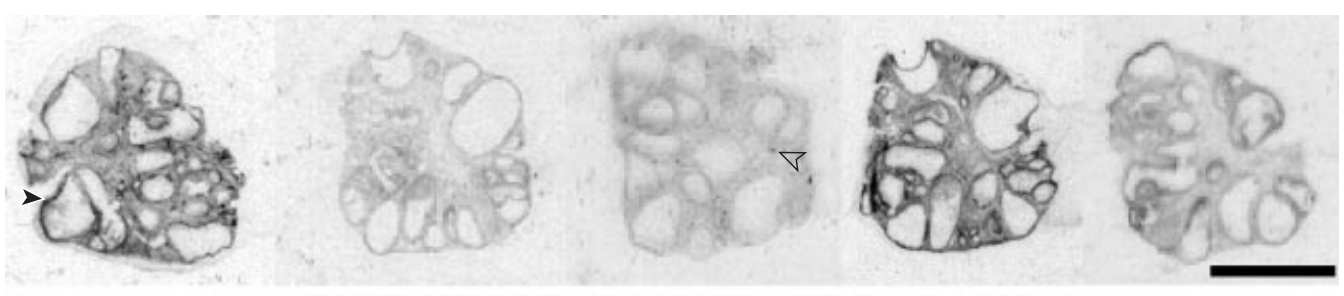

(b)

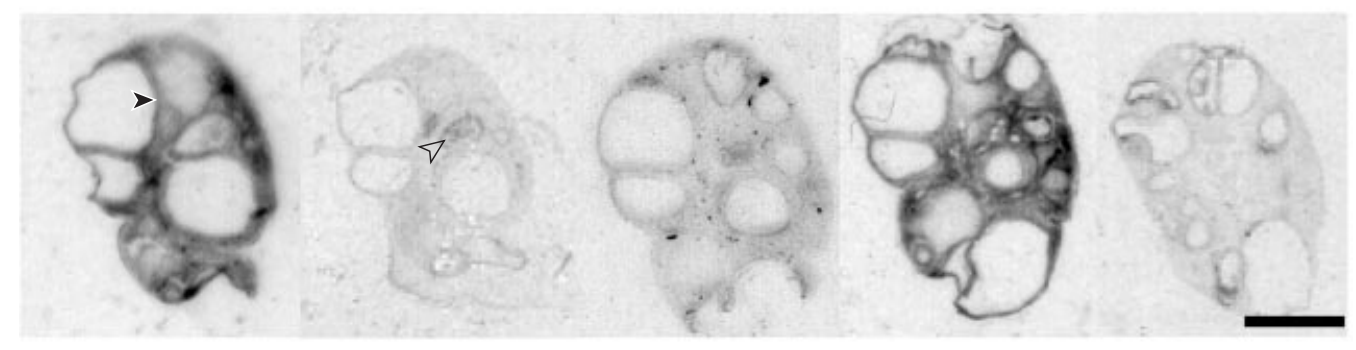

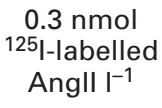

I-labelled
$10^{-6} \mathrm{~mol}$

Ang II I-1



GR117289 I-1

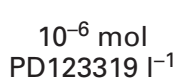

$10^{-6} \mathrm{~mol}$ PD123319 $\mathrm{I}^{-1}+$
$10^{-6} \mathrm{~mol} \mathrm{GR} 117289 \mathrm{I}^{-1}$

Fig. 5. Displacement of ${ }^{125} \mathrm{I}$-labelled angiotensin II (Angll) by $10^{-6} \mathrm{~mol} \mathrm{I}^{-1}$ unlabelled Angll, GR117289 and PD123319 in pig (a) prepubertal and (b) postpubertal ovarian tissue. Note the presence of binding to blood vessels, particularly in those sections corresponding to addition of unlabelled Angll or GR117289 (examples indicated by open arrowheads), and binding in the theca interna-granulosa cell layer of antral follicles (examples indicated by closed arrowheads). Scale bar for each series represents $5 \mathrm{~mm}$ (note different magnifications).

pig ovary, yet does not establish the presence of $\mathrm{AT}_{2}$ receptors conclusively. There was displacement in both tissues at high concentrations of PD123319 that was more clearly observed in postpubertal ovaries. The use of both $\mathrm{AT}_{1}$ and $\mathrm{AT}_{2}$ antagonists on the same section resulted in a shift in the displacement curve from that using just GR117289, implying the presence of a small number of $\mathrm{AT}_{2}$ receptors in these tissues. Thus, it appears $\mathrm{AT}_{2}$ receptors are present in postpubertal tissues, a finding that is in agreement with the contention that this receptor is linked strongly to apoptosis and growth regulation, although the results of the immunocytochemical study indicate that these receptors are not associated with antral follicles. However, $\mathrm{AT}_{2}$ receptors were also associated with the granulosa cell layer of follicles in the prepubertal ovary and their putative role in this tissue needs to be clarified.

Treatment of isolated rabbit thecal and granulosa cell cultures with Angll leads to a decrease in oestradiol secretion and an increase in thecal cell testosterone production, but does not affect the release of progesterone from granulosa cells (Feral et al., 1996). The addition of Angll to cultured rat granulosa cells also elicits no change in progesterone production (Cannon et al., 1997). The results from Feral et al. (1996) indicate that Angll plays a role in steroid synthesis by inhibiting aromatase activity. However, two studies on luteinized human granulosa cells in vitro demonstrated that the addition of Angll leads to an increase in progesterone synthesis (Morris et al., 1994; Johnson et al., 1997), indicating a modulatory action on $3 \beta$-hydroxysteroid dehydrogenase (3ß-HSD; Johnson et al., 1997). Treatment with the non-specific receptor blocker saralasin resulted in enhanced oestradiol production, indicating that oestradiol secretion is inhibited by endogenous Angll (Morris et al., 1994). It has been suggested that Angll reduces the ability of cultured prepubertal pig granulosa cells to synthesize steroids by inhibiting $\mathrm{LH}$-induced transcription of the $3 \beta$ HSD gene or by altering the stability of $3 \beta-H S D$ mRNA, and that Angll stimulates apoptosis in a subpopulation of cells (Li et al., 1995). The ability to produce steroids differentiates between healthy and atretic follicles (Daud et al., 1988). In rats, $\mathrm{AT}_{2}$ receptors inhibit $\mathrm{FSH}$ actions and mediate follicle atresia through granulosa cell apoptosis (Kotani et al., 1999).

In conclusion, the present study has demonstrated the presence of specific binding sites for Angll within the preand postpubertal pig ovary. The receptors were predominantly $\mathrm{AT}_{1}$, a subtype associated with the classical effects of Angll, such as on water and salt balance, and which may therefore be associated with fluid transfer into the follicle. High concentrations of $\mathrm{AT}_{1}$ receptors were present in the granulosa cell layer of antral follicles of both pre- and postpubertal ovaries, in contrast to reports in other species 
(a)

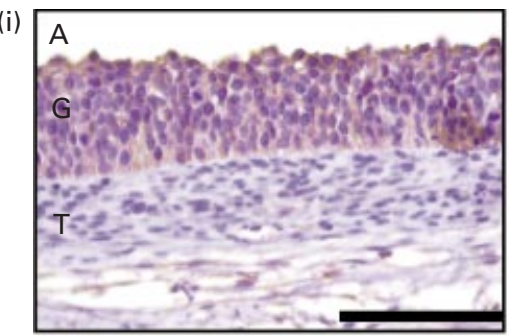

(b)

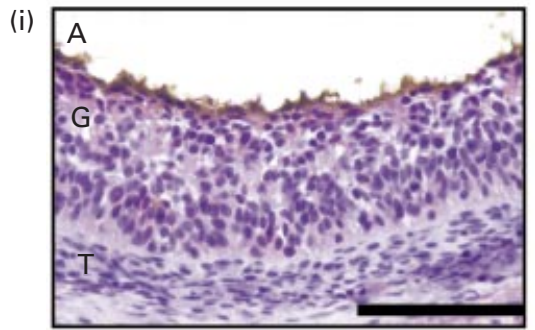

(ii) $A$
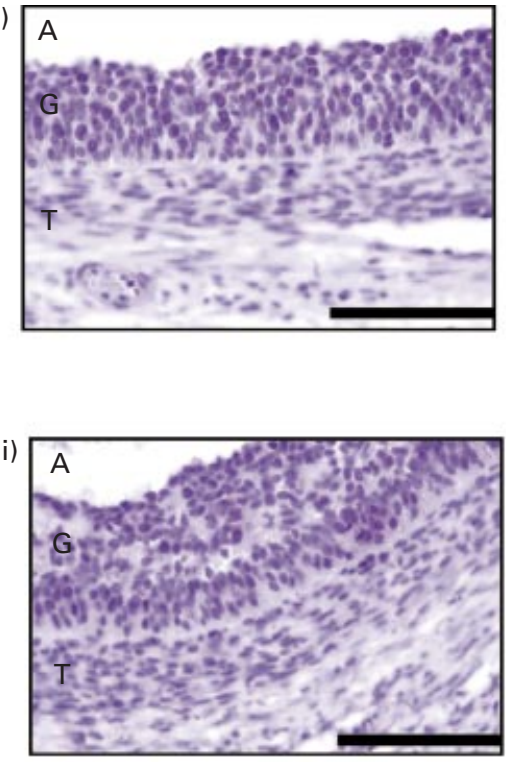

(iii)

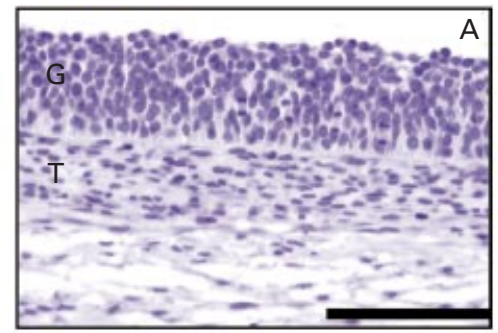

(iii)



(c)

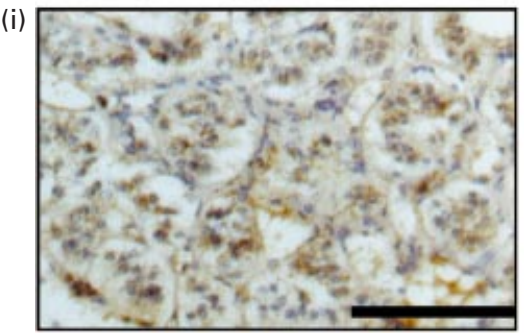

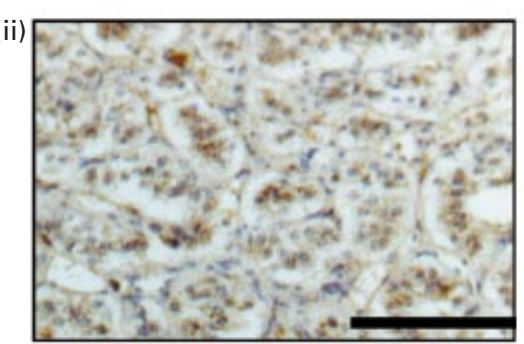



Fig. 6. Immunochemical staining for angiotensin II receptor subtype-specific non-peptide antagonists for receptor subtype 1 $\left(\mathrm{AT}_{1}\right.$ ) (i) or $\mathrm{AT}_{2}$ (ii) receptors in pig (a) prepubertal ovarian tissue (b) postpubertal ovarian tissue, and (c) adrenal medulla. The negative control is presented in (iii). A: antral space; G: granulosa cells; T: thecal cells. Scale bars represent $100 \mu \mathrm{m}$.

in which $\mathrm{AT}_{2}$ receptors dominate and have been suggested to be associated with apoptosis and angiogenesis. Low concentrations of $\mathrm{AT}_{2}$ receptors were present within the prepubertal ovary, although localization of this receptor remains to be clarified for postpubertal ovaries. These data indicate that there are differences in the expression of Angll receptor subtypes and therefore variations in the role of Angll in the ovaries of different species.

The authors would like to thank C. Pearson (University of Sheffield) for assistance and advice with densitometry, G. P. Vinson (University of London) and W. T. Cheung (University of Hong Kong) for generous gifts of antibodies to $\mathrm{AT}_{1}$ and $\mathrm{AT}_{2}$ receptors, respectively.

\section{References}

Aguilera G, Millan MA and Harwood JP (1989) Angiotensin II receptors in the gonads American Journal of Hypertension 2 395-402

Aiyar N, Griffin E, Edwards R, Weinstock J, Samanen J and Nambi P (1993) Characterization of bovine ovary angiotensin II receptors using subtypeselective antagonists Pharmacology 46 1-8
August P and Sealey JE (1990) The renin-angiotensin system in normal and hypertensive pregnancy and in ovarian function. In Hypertension: Pathophysiology, Diagnosis and Management pp 1761-1778 Eds JH Laragh and BM Brenner. Raven Press Ltd, New York

Barker S, Marchant W, Ho MM, Puddefoot JR, Hinson JP, Clark AJL and Vinson GP (1993) A monoclonal antibody to a conserved sequence in the extracellular domain recognizes the angiotensin II $\mathrm{AT}_{1}$ receptor in mammalian target tissues Journal of Molecular Endocrinology 11 $241-245$

Brunswig-Spickenheier B and Mukhopadhyay AK (1992a) Angiotensin II (AII) receptors in the bovine ovary are regulated by LH FASEB Journal $\mathbf{6}$ A1861 (Abstract)

Brunswig-Spickenheier B and Mukhopadhyay AK (1992b) Characterization of angiotensin II receptor subtype on bovine thecal cells and its regulation by luteinizing hormone Endocrinology 131 1445-1452

Bumpus FM, Pucell AG, Daud AI and Husain A (1988) Angiotensin II: an intraovarian regulatory peptide American Journal of the Medical Sciences 295 406-408

Cannon CM, Keeble SC and Curry TE (1997) Effect of A23187 or angiotensin II on ovarian metalloproteinase inhibitors and steroidogenesis in rats Journal of Reproduction and Fertility 111 71-79

Chiu AT, Herblin WF, McCall DE et al. (1989) Identification of angiotensin II receptor subtypes Biochemical and Biophysical Research Communications 165 196-203

Cox BE, Word RA and Rosenfeld CR (1996) Angiotensin II receptor 
characteristics and subtype expression in uterine arteries and myometrium during pregnancy Journal of Clinical Endocrinology and Metabolism 81 49-58

Daud AI, Bumpus FM and Husain A (1988) Evidence for selective expression of angiotensin II receptors on atretic follicles in the rat ovary: an autoradiographic study Endocrinology 122 2727-2734

Daud AI, Bumpus FM and Husain A (1989) Angiotensin II - does it have a direct obligate role in ovulation? Science 245 870-871

Daud AI, Bumpus FM and Husain A (1990) Characterization of angiotensin l-converting enzyme (ACE)-containing follicles in the rat ovary during the estrous cycle and effects of ACE inhibitor on ovulation Endocrinology 126 2927-2935

Feral C, Benhaim A and Leymarie P (1996) Angiotensin receptor type 1 on granulosa and thecal cells of rabbit preovulatory follicles Biochimica et Biophysica Acta 1284 221-226

Grant SA, Hunter MG and Foxcroft GR (1989) Morphological and biochemical characteristics during ovarian follicular development in the pig Journal of Reproduction and Fertility 86 171-183

Hagemann A, Nielsen AH, Dantzer V, Avery B and Poulsen K (1992) Measurement and identification of prorenin and renin in ovarian follicular fluid from cattle and pig Clinical and Experimental Pharmacology and Physiology 19 267-273

Husain A, Bumpus FM, De Silva P and Speth RC (1987) Localization of angiotensin II receptors in ovarian follicles and the identification of angiotensin II in rat ovaries Proceedings National Academy of Sciences of the USA 84 2489-2493

Hutz RJ, Wagner N, Krause P, Fisher C, Syed N, Dierschke DJ, Monniaux D and Tomanek M (1993) Localization of estrogen receptors in rhesus monkey ovary American Journal of Primatology 31 299-309

Israel A, Correa FMA, Niwa M and Saavedra JM (1984) Quantitative determination of angiotensin II binding sites in rat brain and pituitary gland by autoradiography Brain Research 322 341-345

Israel A, Plunkett LM and Saavedra JM (1985) Quantitative autoradiographic characterization of receptors for angiotensin II and other neuropeptides in individual brain nuclei and peripheral tissues from single rats Cellular and Molecular Neurobiology 5 211-222

Jackson P and Blythe D (1993) Immunolabelling techniques for light microscopy. In Immunocytochemistry: A Practical Approach pp 15-42 Ed. JE Beesley. IRL Press, Oxford

Johnson MC, Vega M, Vantman D, Troncoso JL and Devoto L (1997) Regulatory role of angiotensin II on progesterone production by cultured human granulosa cells. Expression of angiotensin II type-2 receptor Molecular Human Reproduction 3 663-668

Kakar SS, Sellers JC, Devor DC, Musgrove LC and Neill JD (1992) Angiotensin II type-I receptor subtype cDNAs: differential tissue expression and hormonal regulation Biochemical and Biophysical Research Communications 183 1090-1096

Kotani E, Sugimoto M, Kamata H et al. (1999) Biological roles of angiotensin II via its type 2 receptor during rat follicle atresia American Journal of Physiology, Endocrinology and Metabolism 39 E25-E33

Li XM, Juorio AV and Murphy BD (1995) Angiotensin II interferes with steroidogenesis in porcine granulosa cells Biology of Reproduction $\mathbf{5 3}$ 791-799

Lightman A, Jones CL, Maclusky NJ, Palumbo A, De Cherney AH and Naftolin F (1988) Immunocytochemical localization of angiotensin II immunoreactivity and demonstration of angiotensin II binding in the rat ovary American Journal of Obstetrics and Gynecology 159 526-530

Lightman A, Palumbo A, De Cherney AH and Naftolin F (1989) The ovarian renin-angiotensin system Seminars in Reproductive Endocrinology 7 79-87

Morris RS, Francis MM, Do YS, Hsueh WA, Lobo RA and Paulson RJ (1994) Angiotensin II (AII) modulation of steroidogenesis by luteinized granulosa cells in vitro. Journal of Assisted Reproduction and Genetics 11 117-122

Naftolin F, Andrade-Gordon P, Pellicer A, Palumbo A, Apa R, Zreik T, Yoon TK and De Cherney A (1989) Angiotensin II - does it have a direct obligate role in ovulation? (response) Science 245871

Nielsen AH, Hagemann A, Svenstrup B, Nielsen J and Poulsen K (1994a) Angiotensin II receptor density in bovine ovarian follicles relates to tissue renin and follicular size Clinical and Experimental Pharmacology and Physiology 21 463-469

Nielsen AH, Hagemann A, Svenstrup B, Nielsen J and Poulsen K (1994b) Relationship of tissue renin and follicular size with angiotensin II receptor density in bovine ovarian follicles Regulatory Peptides $\mathbf{5 3} 149$

Nielsen AH, Hagemann A, Avery B and Poulsen K (1995) Differences in expression of angiotensin II receptors and renin in porcine and bovine ovaries Experimental and Clinical Endocrinology and Diabetes 103 332-338

Obermuller N, Schlamp D, Hoffmann S, Gentili M, Inagami T, Gretz N and Weigel M (1998) Localization of the mRNA for the angiotensin receptor subtype $2\left(\mathrm{AT}_{2}\right)$ in follicular granulosa cells of the rat ovary by nonradioactive in situ hybridization Journal of Histochemistry and Cytochemistry $\mathbf{4 6}$ 865-870

Otani H, Yamoto M, Fujinaga H and Nakano R (1996) Presence and localization of endothelin receptor in the rat ovary and its regulation by pituitary gonadotrophins European Journal of Endocrinology 135 449-454

Palacios JM, Niehoff DL and Kuhar MJ (1981) Receptor autoradiography with tritium sensitive film: potential for computerized densitometry Neuroscience Letters 25 101-105

Pellicer A, Palumbo A, De Cherney AH and Naftolin F (1988) Blocking of ovulation by an angiotensin antagonist Science 240 1660-1661

Perks CM, Denning-Kendall PA, Gilmour RS and Wathes DC (1995) Localization of messenger ribonucleic acids for insulin-like growth factor I (IGF-I), IGF-II, and the type I IGF receptor in the ovine ovary throughout the estrous cycle Endocrinology 136 5266-5273

Peterson CM, Zhu C, Mukaida T, Butler TA, Woessner JF and LeMarie WJ (1993) The angiotensin II antagonist saralasin inhibits ovulation in the perfused rat ovary American Journal of Obstetrics and Gynecology 168 $242-245$

Pucell AG, Hodges JC, Sen I, Bumpus FM and Husain A (1991) Biochemical properties of the ovarian granulosa cell type 2-angiotensin II receptor Endocrinology 128 1947-1959

Robertson JM, Barnes JC, Drew GM et al. (1992) Pharmacological profile of GR117289 in vitro: a novel, potent and specific non-peptide angiotensin $\mathrm{AT}_{1}$ receptor antagonist Journal of Pharmacology 107 $1173-1180$

Saavedra JM, Israel A, Plunkett LM, Kurihara M, Shigematsu K and Correa FMA (1986) Quantitative distribution of angiotensin II binding sites in rat brain by autoradiography Peptides 7 679-687

Shuttleworth, G (2000) Porcine Ovarian Follicle Development and the Renin-Angiotensin System PhD Thesis, University of Nottingham

Som P, Yonekura Y, Oster ZH et al. (1983) Quantitative autoradiography with radiopharmaceuticals, part 2: applications in radiopharmaceutical research: concise communication Journal of Nuclear Medicine $\mathbf{2 4}$ 238-244

Speth RC, Bumpus FM and Husain A (1986) Identification of angiotensin II receptors in the rat ovary European Journal of Pharmacology $\mathbf{1 3 0}$ 351-352

Tian Y, Baukal AJ, Sandberg K, Bernstein KE, Balla T and Catt KJ (1996) Properties of $\mathrm{AT}_{1 \mathrm{a}}$ and $\mathrm{AT}_{1} \mathrm{~b}$ angiotensin receptors expressed in adrenocortical Y-1 cells American Journal of Physiology 270 E831-E839

Timmermans PBMWM, Wong PC, Chiu AT et al. (1993) Angiotensin II receptors and angiotensin II receptor antagonists Pharmacological Reviews 45 205-251

Whitebread S, Meme M, Kamber B and de Gasparo M (1989) Preliminary biochemical characterisation of two angiotensin II receptor subtypes Biochemical and Biophysical Research Communications 163 284-291

Yamoto M, Shima K and Nakono R (1992) Gonadotrophin receptors in human ovarian follicles and corpora lutea throughout the menstual cycle Hormone Research 37 5-11

Yang Y, Macdonald GJ and Duggan KA (1994) Differential regulation of uterine and glomerular angiotensin II receptors in normal and hypertensive pregnancy in the rat Clinical and Experimental Pharmacology and Physiology 21 253-256

Yiu AKL, Wong PF, Yeung SY, Lam SM, Luk SKS and Cheung WT (1997) Immunohistochemical localization of type-II $\left(\mathrm{AT}_{2}\right)$ angiotensin receptors 
with a polyclonal antibody against a peptide from the C-terminal tail Regulatory Peptides 70 15-21

Yonekura Y, Brill AB, Som P, Bennett GW and Fand I (1983) Quantitative autoradiography with radiopharmaceuticals, part 1: digital film-analysis system by videodensitometry: concise communication Journal of Nuclear Medicine 24 231-237

Yoshimura Y, Karube M, Koyama N, Shiokawa S, Nanno T and Nakamura Y (1992) Angiotensin II directly induces follicle rupture and oocyte maturation in the rabbit FEBS Letters 307 305-308

Zilles K, Schleicher A, Rath M and Bauer A (1988) Quantitative receptor autoradiography in the human brain: methodical aspects Biochemistry $90129-137$

Zilles K, zur Nieden K, Schleicher A and Traber J (1990) A new method for quenching correction leads to revisions of data in receptor autoradiography Histochemistry 94 569-578

Resubmitted manuscript received 26 February 2001.

First decision 3 May 2001.

Accepted 3 July 2001. 